\title{
WPS3407
}

\section{STATE OWNERSHIP: A RESIDUAL ROLE? ${ }^{1}$}

\section{Enrico Perotti}

Univerity of Amsterdam

\section{World Bank Policy Research Working Paper 3407, September 2004}

The Policy Research Working Paper Series disseminates the findings of work in progress to encourage the exchange of ideas about development issues. An objective of the series is to get the findings out quickly, even if the presentations are less than fully polished. The papers carry the names of the authors and should be cited accordingly. The findings, interpretations, and conclusions expressed in this paper are entirely those of the authors. They do not necessarily represent the view of the World Bank, its Executive Directors, or the countries they represent. Policy Research Working Papers are available online at http://econ.worldbank.org.

\footnotetext{
* The Global Corporate Governance Forum has commissioned a series of discussion papers that will help improve the understanding of corporate governance reform in developing countries. These papers discuss a number of issues raised by various regional corporate governance research network meetings organized by the Forum to support corporate governance research and policy discussion in developing countries. Comments on these papers are welcome and should be sent to the authors and copied to the Forum (cgsecretariat@worldbank.org). The full series of discussion papers can be found on the Forum's website at http:www.gcgf.org.

${ }^{1}$ I am grateful to Erik Feijen for excellent research assistance and Stijn Claessens for useful discussion.
} 


\begin{abstract}
In this paper we review the state of thinking on the governance role of state ownership. We argue that a gradual transfer of operational control and financial claims over state assets remains the most desirable goal, but needs to be paced so as to avoid regulatory capture and the capture of the privatization process itself. In addition, the speed of transfer should be timed on the progress in developing a strong regulatory governance system, to which certain residual rights of intervention must be vested. In many countries, institutional weakness limits regulatory capacity and reliability, yet our conclusion is that in such environments maintaining sate control undermines the very emergence of institutional capacity, and so the balance should tip toward progressively less direct state control.

After all, what are "institutions" if not governance mechanisms with some degree of autonomy from both political and private interests? The gradual creation of institutions partially autonomous from political power must become central to the development of an optimal mode of regulatory governance.

We advance some suggestions about creating maximum accountability in regulatory governance, in particular creating an internal control system based on a rotating board representative of users, producers and civil society, to be elected by a process involving frequent reporting and disclosure.
\end{abstract}




\section{Introduction}

In this paper we review the state of thinking on the governance role of state ownership and discuss some new directions and recent developments.

A sweeping nationalization movement took place starting with World War I in Europe, as public demand for greater social control over markets followed a series of devastating financial crises (hyperinflation, the 1929 stock market crash, banking crises) and the Great Depression. The process continued in some countries after the World War II. In addition, decolonization created many new independent states eager to engage in nation building and promote development.

Yet the post-war experience led to a drastic rethinking over time. Evidence confirmed the inefficiency of state-owned enterprises, questioned the motives of politicians in establishing direct control for regulatory purposes and challenged the social equity of favoring specific constituencies at high public costs. ${ }^{2}$

In response, in the last two decades a massive privatization process of productive and other activities previously considered public services has taken place across the world. Privatization in developing countries has been spurred since the IMF and the World Bank started to make their assistance conditional on privatization.

After 20 years of this process, the borders of state ownership have been dramatically redrawn in many countries. The process has unquestionably been quite successful overall (Megginson, 2001). Yet the experience of privatization applied to certain sectors or countries has ultimately raised objections and resistance even among early and committed proponents, who find that privatization in some contests creates serious risks (Nellis, 1999), which we interpret as the result of public capture of the process. While privatization has yet to run its course in many countries and sectors, recent experiences in Latin America and Eastern Europe require that we seek to understand better its limits.

\footnotetext{
${ }^{2}$ The debt crisis in the eighties was also a catalyst which forced governments to divest loss making operations to generate revenues. As Laeven and Perotti document (2001), privatization tends to be initiated at times of economic difficulties.
} 
To discuss the relative merits of state and private ownership we thus review the fundamental literature on ownership, discuss the main drivers of political decision making and draw some conclusions on what role state ownership or more generally public governance does and/or should play in regulating economic activity. Section I introduces the issues. Section II reviews the broader conceptual framework. Section III presents our views.

\section{Section I}

SOEs exhibit a significant lower productive efficiency (as distinct from allocative efficiency) in comparison with privately owned counterparts. ${ }^{3}$ The main causes have been traced back to a general lack of accountability, ${ }^{4}$ leading to

a) a lack of managerial and employee incentives to efficiency

b) problems of competence or corruption by state authorities

c) the use of SOEs for political purposes, in favor of favored constituencies

Boardman and Vining (1992) also concluded that SOEs may undermine the existence of private competitors.

There are striking parallels between the governance problems caused by state ownership or by diffuse private ownership. The free-rider problem applies to taxpayers even more so than to dispersed shareholders; moral hazard may be enhanced under state ownership since the powers of government are greater than private management and thus harder to control (Perotti, 1994); and limited disclosure is probably a greater problem in

\footnotetext{
${ }^{3}$ We will not review empirical findings on the efficiency of privatization across countries. Good surveys are found in for instance in World Bank (1995), Megginson et al (1994), McKenzie and Mookherjee (2002), and Boubakri and Cosset (1999).

${ }^{4}$ We mean accountability to citizens, not investors. While SOEs are incorporated firms, they have no scrutinizing equity market investors; nor do lenders play a disciplining role, as SOE debt is perceived as a public obligation.
} 
state than in private companies (Vickers and Yarrow (1989)) in the absence of institutions empowered to audit state decisions. ${ }^{5}$

Two arguments are used for justifying state ownership in the presence of market failures such as market power or externalities (see e.g. Esfahani and Ardakani, 2002). The first (which we term the 'public commitment problem') concerns the inability of a sovereign government to commitment to market-friendly tax and regulatory policies, which discourages private investment and may result in direct government involvement in production as a substitute. The approach takes the view that politicians have difficulties credibly committing to refrain from tax and regulation manipulation to collect quasi-rents. For instance, state control of infrastructure may be the result of the unwillingness of private investors to fund large ex ante investments whose rewards, once sunk, are subject to political decisions. The second (which we term the "private commitment problem') identifies the difficulty for regulators in controlling significant decisions by private owners, unless government has direct control over the enterprise (see Hart et al. (1997); Shleifer and Vishny (1994)). For instance, state ownership of banks may arise because private banks take advantage of depositors (as in Russia) or of deposit insurance.

In the public commitment approach, the inability to commit arises from sovereign authority (the monopoly of authority) and may lead to inefficiency when coupled with biased preferences and/or political opportunism, leading to corruption, excessive spending or targeting of benefits, which in turn induces excessive taxation or interference. ${ }^{6}$ In the private commitment problem, the difficulty of imposing certain rules on private enterprises may be due to poor institutional mechanisms to control private behavior indirectly and thus justify direct state control. Yet a failure to impose political

\footnotetext{
${ }^{5}$ In fact, we will argue later that the most neglected benefit of privatization is the increase in public scrutiny arising from the fact that political control becomes exercised more at arm-length, or in any case through explicit legislation, so that its goals become more open to public opinion. This is comparable to the case of a firm with many owners obtaining a public listing, a move which improves the quality of information available to judge its management.

${ }^{6}$ Perotti (1995) argues that under uncertain public commitment, governments can credibly inspire confidence by transferring control immediately while selling ownership gradually, signaling its commitment to privatization policy by its willingness to bear residual risk.
} 
wishes on the private sector does not imply that such goals are socially, as opposed to politically, desirable, nor that the state as an owner would perform better.

Both these approaches, which try to formulate a rationale for the "optimal" size of state ownership, presume that state authorities seek to correct market failures such as externalities, natural monopolies, high information costs or public goods. Their justification for government ownership depends critically on this assumption. Yet rather than assuming such a public objective, it is more useful to discuss circumstances and governance forms under which there is enough public scrutiny by citizens to ensure some congruence of political intent and public welfare.

In general, limited commitment applies for both private individuals and state authorities under incomplete private contracting and its public sector counterpart, incomplete legislation. The critical difference is that the sovereign state has greater discretion and thus greater scope for abuse. The main argument against state control arises from the combination of broader discretionary powers and the potential for political opportunism. ${ }^{7}$

We will argue that privatization and open regulation is not only needed for productive efficiency, but also for allocative efficiency, since it is essential for democratic control over the regulatory process. At the same time, we recognize that privatization does fail to deliver much of its potential in poor institutional contexts, and specifically whenever it is difficult to establish regulatory control leading to private commitment to specific goals of social relevance. Even in such context we argue that at most only a temporary form of partial ownership with highly contingent control rights

\footnotetext{
${ }^{7}$ Given that many developing countries have weaker institutions constraining public abuse, the case for state control is particularly difficult precisely in those contexts where the need may be in principle is greatest. Yet the right goal in a dynamic contest should not between state or private ownership, but rather to dedicate the task of state control to be the gradual build up of the institutional framework, which would allow a greater separation of direct political control from productive decisions.
} 
can be justified, based on an explicit agenda for building up over time institutions, which can take on the regulatory task on a more autonomous basis. ${ }^{8}$

Thus in our opinion, the relevant notion of non-private governance needed is regulatory governance. Regulation needs to be explicit, and thus exposes both public policy and private behavior to greater public scrutiny. To function properly in poor institutional context, however, the regulatory institutions need to be developed progressively. We will argue that a more grassroots form of governance concept needs to be recognized, creating legitimacy and scope for progressively more independence from the executive branch of government.

Regulation fails just as privatization does, namely when it leads to regulatory or (in the extreme cases) to state capture. Good examples are the large privatization programs in Chile in the late 1970s, in Mexico in the 1980s and in Russia in the mid 1990s. In some early Latin American privatization programs, large private investors were grossly favored on the privatization of the large state banks, which were sold on the cheap and on highly leveraged terms. This enabled these investors to fund the acquisition of control over a number of privatized firms. In all these cases, the abuse of bank resources for private purposes led to brutal financial crises, which forced renationalization of most of these groups. The Russian experience is also instructive in how captured privatization programs can undermine the authority of the state and other institutions (see Perotti, 2002). In contrast, the Chinese experience of gradual privatization of the economy by favoring entry while retaining control over the process has limited private capture of the process, although it still leaves some uncertainty as there may be gradual retreat.

\footnotetext{
${ }^{8}$ The exception should be those circumstances when loss of state control would lead to uncertainty over the allocation of ultimate control and enforcement. This is evident in the case of executive powers and public security, as in the case of the army, the police or the prisons.
} 


\section{Section II}

Do politicians maximize social surplus? This is the same as asking if politicians in office represent the interest of the electorate or their own interests. Alternatively stated, the question is whether political markets function efficiently.

Both Sappington and Stiglitz (1987) and Hart et al (1997) show that under the assumption of a benevolent ("helping hand") government, market failures may be addressed by state control. ${ }^{9}$ Sappington and Stiglitz (1987) present the classic argument for state control. They argue that information, contracting and bargaining costs limit the government's ability to regulate by ex ante design. They also suggest that when the government cannot exactly determine its objectives due to lack of experience, it may want to retain direct control to avoid costly contract renegotiation procedures with private parties. ${ }^{10}$ To the extent that intervention has large costs, state ownership (or rather, state control) is to be preferred to private ownership.

Hart et al (1997) adopt a model in the spirit of Coase (1937) on the decision to buy an input on the market or to produce it in-house. ${ }^{11}$ The government must provide a 'basic' good and can either hire public employees, led by a manager, and retain ownership of the assets, or sub-contract with a private supplier with his own employees and assets. The ownership of the assets grants the stronger incentives in an incomplete contract world. The provider of the good can invest time to improve the quality of the service or to reduce its cost, at some adverse effect on quality. Neither action is contractible ex ante, so each innovation needs approval by the owner of the assets. Private ownership is superior to public ownership when the deterioration of quality from

\footnotetext{
${ }^{9}$ Many authors in the past argued that social goals, such as acceleration of technology transfer, increased employment, reduced inequality, and regional development, may be realized via SOEs. The evidence on the long term role of SOEs have largely discredited this view, and have shifted attention to fiscal and regulatory alternatives to achieve these goals.

${ }^{10}$ The argument may cut both ways. Schmidt (1996) argues that privatization is a way for government to credibly deny itself private information about production costs, and therefore force the private manager to reduce costs, since subsidies now will reflect social benefits rather than firm costs.

${ }^{11}$ There are close parallels between theories of the firm and of privatization (Coase (1937); Grossman and Hart (1986; Hart and Moore (1990); Hart (1995)).
} 
cost reduction is small and the government employees have weak incentives to innovate. Thus even state ownership with a benevolent government need not be the best alternative. HSV note that even if a large part of the output is non-contractible, private provision may still be superior, because entrepreneurs have the incentive to provide quality in order to build a reputation with customers and regulators. ${ }^{12}$

Both these papers find an echo in the recent literature on "incomplete legislation" which we address later (Pistor and Xu 2003).

\section{Self-interested government}

A growing strand of the literature takes a positive rather than a normative political economy approach to state ownership and assumes that politicians are able to pursue their own interests at the cost of the common good. If selfish politicians lead to corruption and patronage (Shleifer and Vishny, 1993), then SOEs' inefficiency is due not just to weak incentives, but the result of a deliberate political choice to transfer resources to supporters ${ }^{13}$ (Boyko et al (1993); Shleifer and Vishny (1994)). Such indirect targeting, distorting the productive process, can occur only at some distortionary cost (Bias and Perotti, 2002), such as excessive employment ${ }^{14}$ and wages. In addition, SOEs may build plants in economically unattractive regions (Martinelli (1981)). Other sources of political benefits include the production of goods that are only politically and not socially desirable. ${ }^{15}$ Politicians may even distort the regulatory framework ahead of a SOE sale, by reducing future competition, hence maximizing revenues (or bribes) at the cost of consumer surplus.

\footnotetext{
${ }^{12}$ Vickers and Yarrow (1989) and Schmidt (1996) show that the resulting distribution of the surplus need not be efficient.

${ }^{13}$ Which constituency is favored depends on the determinants of political power. The government may favor politically appointed managers, employees or consumers. Although it is sometimes argued that the government will weigh consumer surplus higher than producer surplus when consumers have more voting power (Vickers and Yarrow, 1989), producers (including workers) have more incentive to lobby and thus are more likely to receive political attention.

${ }^{14}$ Even in the U.S., state entities employ typically $20-30 \%$ more employees than their private counterparts (Donahue (1989)).

${ }^{15}$ The development of the Concorde plane is a good example (Anastassopoulos, 1981).
} 
Empirically, many SOEs have a poor record in solving market failures.

Externalities such pollution were not visibly better managed by SOEs, such as the environmental situation in Eastern Europe illustrates (Grossman and Krueger (1992)). Public monopolies often abuse their market power not necessarily by high prices but by sheer inefficiency, allowing their employees a "quiet life", or by granting preferential treatment to political constituencies (Kikeri, Nellis and Shirley, 1992). This form of internal capture has led to such low rates of investment under state monopoly in many countries. Primary examples are the energy or telecommunication sectors, which often only after privatization and the resulting increase competition has led to an expansion and modernization of the infrastructure. ${ }^{16}$

Perotti (1994) discusses how privatization reduces the effective control of politicians because it confers residual rights of control to the owners, and thus effectively de-politicizes the decision process. Even when politicians may still intervene to pressure privatized firms, e.g. to retain extra labor, privatization changes the bargaining power of the government: it establish some restrain as it transfers a set of residual rights to the private owners (Perotti, 1994) who have strong incentives for resisting value diversion. Under concentrated private ownership, the required subsidies to maintain high employment are too high, and the government stops subsidizing the firm. Thus the budget constraint hardens, and restructuring occurs (Boyko et al, 1996).

The next section offers a broad framing of the conceptual framework on the nature of ownership and its implications for private and state control. We start with the accepted notion that ownership is relevant because we live in a world of incomplete contracting and incomplete legislation.

\footnotetext{
${ }^{16}$ It is precisely such tasks that normative public economics would have assigned to a public firm, since private firms would tend towards under investment and under provision of services.
} 


\section{Section II}

\section{Ownership as Residual Rights of Control}

Under complete contracting, any agency issue interfering with optimal decision making can be managed via explicit arrangements which fully describe the optimal course of action. Then ownership is irrelevant, since all actions in all contingencies are already contracted upon. In this case the allocation of ownership issues has no bearing on efficiency (Hart (1995); Sheshinski and López-Calva (1998)). Any market-driven distortion such as a monopoly power or externalities can be resolved via regulation. Ownership makes a difference to incentives and thus actions because contracts are incomplete (Hart, 1995). ${ }^{17}$ In this context, ownership completes contracting as it assigns to the owner the set of residual control rights over uncontracted or unregulated contingencies. Thus under incomplete contracting there is ambiguity on actual decisions, and control may be assigned to resolve optimally this issue. State ownership is seen as justified when explicit regulation is difficult to implement because of non-verifiable contingencies. For example, quality of incarceration of prisoners or basic medical care are difficult to verify and cannot be easily contracted upon (Hart, Shleifer and Vishny, 1997).

This definition of private property right as a residual set is quite broad. State regulation is presented here as affine to contracts, under the understanding that the law has to be explicitly written down and is thus incomplete. We take issue with this narrow notion. Private ownership only reduces the degree of discretionary control that the state can master over private assets, and only to the extent of constitutional (and even so, effectively enforced) private property protection. Since laws can be changed, the scope for private control may be indefinitely reduced by legislation. Thus, while very valuable

\footnotetext{
${ }^{17}$ Contracts are incomplete because of limited capacity to foresee or fully describe future contingencies, or by limited enforcement due to unobservability or verifiability of events.
} 
in a static setting, this definition is a bit vacuous when the state can expand its regulatory powers by fiat. ${ }^{18}$

Let us come back to the classic argument for state control by Sappington and Stiglitz (1987). The argument, while sensible, is unbalanced. One of the greatest problems in state ownership, even when originally established for justifiable causes, is that it is most difficult to remove once established. Just as any policy-oriented economist knows, any institution created for a temporary purpose will tend to make it a permanent task. Additionally, politicians have multiple goals besides fair regulation. In reality, it may be dispersed citizens that face the difficult task of intervening in state-controlled property to ensure proper governance.

\section{Mixed state ownership}

Some authors (e.g., Che 1997), observing the role that firms formally owned by local authorities, so called township and village enterprises (TVEs), played in China's growth, argue that government ownership can serve as a commitment mechanism through which the government will restrain itself from rent-seeking activities, and even offer support. Yet the de facto allocation of control in the TVEs resembles a private arrangement with involvement of (or direct personal control by) local politicians. It resembles thus a private firm that is able via bribes to obtain access to scarce resources (credit or licenses) as well as worker discipline. Yet this examples refers to productive activities in highly competitive sectors, and thus holds little promise to address the issue of market failure.

A case for temporary mixed ownership is given in Perotti (1995). Under uncertain public commitment, governments can credibly inspire confidence by transferring control immediately while selling ownership gradually, signalling commitment to privatization policy through willingness to bear residual risk. A parallel argument may be made by

\footnotetext{
${ }^{18}$ At the same time, there is some truth to this notion in what lawyers call the elasticity of ownership rights, in the sense that when a regulation is removed, the encumbrance on the property is removed. The extreme case is probably the return to former owners of property in many Central European countries after the fall of the Berlin Wall.
} 
arguing that the public sector should keep control over the decision rights until proper regulation is in place (in the language of Stiglitz and Sappington, until the state learns about its own objectives). In both cases the argument is for temporary, gradually decreasing residual cash flow /control rights. Once ownership is indeed decomposed in these two components, the development of an autonomus regulator framework is just another name for this process. But how to govern the monitor? In other words: how to establish a credible time path for the retreat of the direct control role of the state and the emergence of genuine, more accountable forms of regulation?

In the next section we discuss the open agenda for regulatory governance.

\section{SECTION III}

\section{Regulatory capture}

Privatization outcomes are heavily affected by the institutional setting in which divesture takes place. In countries where public regulation cannot control private activity, the speed of privatization should be aligned with the progressive strengthening of institutional foundations (Nellis (2003)). Privatization can lead to increased efficiency and improved welfare only in settings with enough capacity to ensure appropriate protection of property rights, contract enforcement, control of market abuse, fair regulation and open entry, and commercial dispute settlement based on law, not payments.

At the same time, there are enough cases of poor performance of privatization in some contexts to alert us to some objective limits in private control, primarily due to regulatory inefficiency or outright capture. When the transfer of critical assets to private ownership cannot be managed safely (in the sense of avoiding losing control of the sale and the regulatory process), public control can have a temporary role, while some process of institution-building takes place. Yet to be feasible, the structure and role of this residual ownership form needs to be designed from the beginning for this temporary 
purpose, however long it may take. The suggestion is that without an explicit commitment by the state to release control under some conditions, the process of institution building may not even start.

However, there are countries and circumstances in which there exists a lack of essential institutions to support or regulate private activities such that indeed rapid privatization may lead to an unacceptable loss of control over the economic system. In institutional contexts where there is a danger of significant loss of public control over safety due to privatization, such as in health care or basic infrastructure, outright privatization is not desirable. In such cases, state control is a necessary, if perhaps temporary, intermediate step to support institution building. When privatization cannot escape capture, it may weaken corporate governance (weak regulatory, bankruptcy and take-over procedures, corrupt legal enforcement) and thus lead to a loss of ultimate control over the process and thus its goals. Hence some caution in the speed of privatization is called for. Partial, temporary state ownership may buy some time needed to establish the needed institutional and regulatory frameworks (Nellis (2003)). ${ }^{19}$ The consequences of the failure to build up such institutions are disappointing economic and welfare effects, and a political backlash that sets the state back in control and blocks further institutional development. Yet the state has to be further removed from direct involvement in the economy, in order to progressively create some scope for allocating residual regulatory and enforcement rights in new institutions. The emphasis should be toward creating increasingly professionalized and autonomous regulatory institutions that draw their legitimacy and the right to gain further autonomy from a direct, i.e. nonstate, form of governance that involves consumers and citizens to a greater extent.

This points to a natural sequence of privatization and regulation. First, smaller firms, and generally firms in competitive sectors, can be sold quickly via a transparent, open auction system. Larger firms may be sold more gradually, depending on the need for both confidence building for investors (Perotti, 1994) and regulatory development. Here the experience with the telecommunication industry points to the failure of the

\footnotetext{
${ }^{19}$ For a related discussion on the role of institutions see Shirley and Walsh (2000).
} 
notion of natural monopoly, where the very act of privatizing usually has ensured greater scope for entry and thus self-discipline by the market. Finally, so-called public service activities should be gradually made more autonomus, exposed to competition and introduced to subcontracting. A caveat in this evolution is the risk of demerging firm activities to the point failure to coordinate different activities (such as rail maintenance and train services) or attribute responsibility.

Recent evidence (Acemoglu and Johnson 2003, Djankov et al. 2002) suggests that the most important institutions are those that restrain the executive and reinforce its accountability, i.e. limit abuse of power over those that regulate relationships among individuals. The reason may be that power-restraining institutions also correct political incentives to favor strong private interests, for instance to control market power, and thus undermine a level playing field and the process of entry by new producers. ${ }^{20}$

State capture by special interests seriously weakens the credibility of enforcement. While corruption accompanied transition in all countries, its extent in the FSU (Former Soviet Union) led many authors to describe it as state capture, where the corrupting agents hold more power than the corrupted officials. There is evidence that while connected firms benefit, on average, firms grow less than in less captured economies (Hellmann, Jones and Kaufmann, 2000). In Russia, the private capture of the privatization process weakened the ability of the government to control the behavior of the most powerful private owners (Perotti, 2003).

A way to summarize the case for a further retreat of state ownership even in countries with poor institutions comes from Djankov et al (2002). They argue that the more civic capital a country has, the more it is able to achieve cooperation among its members without coercion. Civic capital, fixed in the short run, is determined by culture, factor endowments, and history. ${ }^{21}$ The less civic capital a country has, the less it can

\footnotetext{
${ }^{20}$ Perotti and Volpin (2003) suggests that in a context of poor political accountability, established interests can lobby successfully to adapt regulation and even selective enforcement in their favor, blocking entry by new firms. Thus institutions reinforcing political and regulatory accountability are a preliminary step to ensure also proper enforcement of relationships among individuals.

${ }^{21}$ An interesting argument is put forward by Acemoglu et al (2002) that early settlers mortality in colonial times affected whether the laws of the colony were set to facilitate extracting and plundering resources and
} 
'buy' order with extra regulation. Thus less developed countries can achieve less with regulation. Deregulation of competitive markets in less developed countries should then count as a high priority. The presence of relatively high barriers to entry in such countries suggests that regulation is often captured and thus tends to hinder growth. But just as barriers to entry must be reduced, the urgency to amend the regulatory institutions increases. We claim that this requires a deliberate policy toward greater scrutiny and accountability via a more directly elected form of regulatory governance.

\section{Regulatory governance}

We have drawn so far a basic conclusion. Both private agents and the public sector face commitment problems because of incomplete information, incomplete contracts and incomplete legislation. Since governments are sovereign institutions, they have more difficulty in committing to specific decision criteria than the private sector. They should ideally be constrained by private ownership, and the private sector should be constrained by regulation. Thus the critical question shifts to the governance of the regulatory institutions.

Regulatory authorities have grown throughout the developed and developing world as a result of privatization, and exhibit various degrees of autonomy. ${ }^{22}$ We will make the point here that whatever the record, the separation of tasks tends to generate additional open scrutiny and necessarily improves the governance of the regulatory process, at least as long as it is not captured. ${ }^{23}$

In the language of Pistor and $\mathrm{Xu}$ (2002), laws and regulations are necessarily incomplete, just as contracts are. By default, residual rights to regulate belong to the state.

\footnotetext{
thus aimed at social control or to protect the rights of settlers from the mother country. For related evidence, see Engerman and Sokoloff (2000).

${ }^{22}$ Many frequently levied critics to the effectiveness of regulators have to recognize that inefficiency in the past was less observable as it was buried inside a ministry or a public budget.

${ }^{23}$ Regulatory capture can occur either because of uncontrolled abuse by politicians, or because beneficiaries are dispersed while producers have concentrated benefits.
} 
Yet the authority to adjust enforcement under unspecified contingencies could be granted to semiautonomous judiciary or regulatory authorities. The role of regulatory agencies is more proactive than courts, which may respond only after damaged parties bring legal action and may not intervene preventively.

Provided such institutions operate under a framework in which they can avoid being captured, granting them progressively increasing residual enforcement rights has several advantages over the assertion of direct state control.

Currently the degree of regulatory autonomy is politically controlled. In perspective, regulatory governance could be made contingent on public approval in similar ways as the public sector. As long as the mandate is both explicit and focused, and a reputation can be established (as for central banks), such institutions have less power and appetite for secondary political goals. Besley and Choate (2003) argue along similar lines that politically appointed regulators tend to pursue unrelated political goals. They report evidence that US states with elected regulators in place of political appointees choose more pro-consumer policies.

The ability to ensure that regulators act in an independent and accountable fashion towards their stated goals can be reinforced by a novel approach to their governance. Their mandate should be temporary and subject to public review: their governance should include representatives of consumers and other nongovernmental organizations. There are traditional forms of institutional governance, such as in mutual banks or administrations of public infrastructure, in which there are elected representatives of users. This concept should be broadened and further experimented in other contexts as well.

An important distinction needs to be made between NGOs and grassroots organizations. Especially in developing countries, grassroots organizations are arrangements around specific shared interest by the population (say small farmers or craft makers, or neighbourhood organizations). They are usually detached from the political system and relatively communal in nature. In contrast, NGOs are often foreign-inspired, staffed with more educated individuals, often driven by some strong vision. They are better politically connected, or at the very least have some access to foreigners in terms of 
either funding or visibility. Clearly, the two types of organization are complementary. It could be particularly interesting to create stronger links between the ability of NGOs to mobilize external resources or broader attention and the ability of grassroots organizations to mobilize support or public opinion. They should therefore have distinct roles in regulatory governance, yet they may also become encouraged to cooperate more to ensure that fundamental needs may rise to the attention of the regulatory system.

In conclusion, we argue that the governance process of regulators should take a more democratic, directly elected turn. The logic of the argument is not democratization per se; there are agency and common good problems to this solution as well as to others. The logic of this proposal reflects the sensible economic principle that those who have the greatest benefit from proper regulations should be at least in part entrusted with its governance (Bestley, 2000). Thus the composition of a regulatory board may include representatives from different constituencies and nongovernmental organizations, elected on a rotational basis from broad lists. ${ }^{24}$ The governance assignments of individual organizations may be made temporary, and extensions and rotation may be made subject to public, rather than political, approval. Importantly, the regulators should be subject to various forms of explicit accountability by the establishment of specific quantifiable or verifiable goals, and they would need to report on an annual basis as to their achievements. A task of the external appointees would be then to report publicly on their view on the regulatory effort, and contribute to adjust the statement of regulatory intents and their priorities by increasing public scrutiny.

\footnotetext{
${ }^{24}$ A strong advantage of nongovernmental organizations, when allowed to express freely, is that they are harder to capture. On the other hand, one should caution against excessive enthusiasm for NGOs, particularly in contexts in which there is too little choice among them. Raising their importance also requires increased transparency in their budgets and activities.
} 


\section{Conclusions}

The issue of public versus private governance in circumstances of market failure hinges on the relative ability to commit to a fair and efficient allocation. We have argued that the state has on average greater difficulty in committing, due to its status. State control should remain an extreme solution, not advisable except in circumstances when privatization leads to uncertainty over the allocation of ultimate control. This is evident in the case of executive powers and public security, as in the case of the army, the police or the prisons.

In countries where private commitment is hindered by poor legal enforcement, a case can be made for some form of state control. Yet because such environments are also commonly associated with corrupt politicians and unconstrained abuse of power, the public commitment problem is here even more serious. The evidence in the recent literature clearly points to institutional development as a precondition for the functioning of both private and public policy (see Acemoglu et al (2003) on macroeconomic instability in poor institutional environments), which produce worse outcomes even after controlling for policy choices.

The conclusion is that in such environments there is too little institutional capacity for proper state-controlled regulation, and thus the balance should be for less direct state control.

Of course, this is only a static view. The fact that an institutional framework is too weak to support active state regulation suggests that institutional capacity has to be built up, not forsaken. What are institutions if not governance mechanisms with some degree of autonomy from both political and private interests? The gradual creation of institutions partially autonomous from political power becomes central to the development of an optimal mode of regulatory governance. 
In conclusion, a residual degree of state control, rather than outright ownership, may have a role when proper institutional mechanisms are not (yet) in place. Yet this role must be progressively reduced by the creation of intermediate, focused regulatory institutions that may offer some weakening of the political grip on decision making. Forcing separation of enterprises from ministries, ensuring their incorporation ownership, establishing independent regulators and ensuring their progressive autonomy in residual regulatory rights, and moving to a temporary mix may create a dynamic decrease in the residual role of the state via greater exposure to market discipline and incentives, while increasing accountability. ${ }^{25}$

\footnotetext{
${ }^{25}$ Kikeri et al (1992) review some lessons form privatization experience', and emphasize how regulation is critical to the success of privatization. Transparency via competitive bidding procedures, coupled with objective selection criteria for bids, is critical for the economic and political success of the process. In the end, these lessons reinforce the arguments for shifting attention to regulatory governance.
} 


\section{REFERENCES}

Acemoglu, Daron, Simon Johnson, James Robinson, and Yunyong Thaicharoen (2003). 'Institutional Causes, Macroeconomic Sumptoms: Volatility, Crises and Growth', Journal of Monetary Economics.

Anastassopoulos, Jean-Pierre C. (1981). 'The French Experience: Conflicts with Government'. State-owned enterprise in the Western Economies. London: Croom Helm, pp. 99-116.

Besley, Timothy and Stephen Coate, "Elected versus Appointed Regulators: Theory and Evidence", LSE mimeo, March 2003.

Biais, Bruno and Enrico Perotti (2002). "Machiavellian Privatization". American Economic Review, 92(1), p. 240-258.

Boardman and Vining (1992). "Ownership Versus Competition: The Causes of Government Enterprise Inefficiency," Public Choice 73:2, 205-239.

Boubakri, Narjess, and Jean-Claude Cosset (1999). 'Does Privatization meet the Expectations? Evidence from African Countries'. Mimeo. African Economic Research Consortium, Nairobi.

Boycko, Maxim, Andrei Shleifer, and Robert. W Vishny (1996). 'A Theory of Privatization'. The Economic Journal, Volume 106, Issue 435, pp. 309-319.

Che, Jiahua, "Rent Seeking and Government Ownership of Firms: An Application to China's Township-Village Enterprises" (September 2002). William Davidson Institute Working Paper No. 479.

Coase, Ronald (1937). 'The Nature of the Firm'. Economica, 4, pp. 386-405.

Donahue, John D. (1989). 'The Privatization Process'. New York: Basic Books. 
Djankov, S., Edward L. Glaeser, Rafael La Porta, Florencio Lopez-de-Silanes, and Andrei Shleifer (2003). 'The New Comparative Economics'. CEPR Discussion Paper in Transition Economics.

Engerman Stanley L. and Kenneth L. Sokoloff (2000). "History Lessons: Institutions, Factor Endowments, and Paths of Development in the New World", Journal of Economic Perspectives, 14(3).

Esfahani, Hadi Salehi and Ali Toossi Ardakani (2002). 'What Determines the Extent of Public Ownership?'. Working paper, University of Illinois at Urbana-Champaign Grossman, Sanford and Oliver Hart (1986). 'The Costs and Benefits of Ownership: A Theory of Vertical and Lateral Integration'. Journal of Political Economy 94, pp. $175-202$.

Grossman, Gene and Alan B. Krueger (1995) "Economic Growth and the Environment". Quarterly Journal of Economics, 110(2), pp. 353-77.

Hart, Oliver (1995). 'Corporate Governance: Some Theory and Implications', The Economic Journal, 105(430), pp. 678-689.

Hart, Oliver (2002). 'Incomplete Contracts and Public Ownership: Remarks and an Application to the Public-Private Partnerships'. Mimeo, Harvard University.

Hart, Oliver and John Moore (1990). 'Property Rights and the Nature of the Firm', The Journal of Political Economy, 98(6), pp. 1119-1158.

Hart, Oliver, Andrei Shleifer, Robert W. Vishny (1997). 'The Proper Scope of Government: Theory and an Application to Prisons'. The Quarterly Journal of Economics, Volume 112, issue 4, pp. 1127-1161.

Hellmann, J. Jones, G. and Kaufmann, D., (2000), "Seize the State, Seize the Day", World Bank Policy Research Paper 2444. 
Kikeri, Sunita, John Nellis, and Mary Shirley (1992). 'Privatization: Eight Lessons From Experience'. Policy Views, World Bank, Country Economics Department, www.worldbank.org/html/prddr/outreach/or3.htm

La Porta, Rafael, Florencio Lopez-de-Silanes, Andrei Shleifer, and Robert W. Vishny (1998). 'The Quality of Government'. Mimeo, Harvard University.

Laeven, Luc and Enrico Perotti (2001), 'Confidence Building and Emerging Market Development', CEPR Discussion paper no. 3055, November, London.

Martinelli, Alberto (1981). 'The Italian Experience: Conflicts with Government'. State-owned enterprise in the Western Economies. London: Croom Helm, pp. 85-98.

McKenzie, David, and Dilip Mookherjee (2003). 'The Distributive Impact of Privatization in Latin America: Evidence from Four Countries'. Economia, Spring 2003, 161-218.

Megginson William L., and Jeffry M. Netter (2001). 'From State to Market: A Survey of Empirical Studies on Privatization'. Journal of Economic Literature (Forthcoming).

Megginson, William L., Robert C. Nash, Matthias Van Randenborgh (1994). The Financial and Operating Performance of Newly Privatized Firms: An International Empirical Analysis'. The Journal of Finance, Volume 49, Issue 2, pp. 403-452.

Modigliani, Franco and Enrico Perotti, "Security Markets versus Bank Finance: Legal Enforcement and Investor Protection", International Review of Finance, vol. 1 no 2, p. 81-96, 2000.

Nellis, John (1999). 'Time to Rethink Privatization in Transition Economies?', Finance and Development, 36(2). 
Nellis, John (2003). 'Privatization in Africa: What has happened? What is to be done?'. Center for Global Development, Working paper.

Perotti, Enrico (1994). "A Taxonomy of Post-Socialist Financial Systems: Decentralized Enforcement and the Creation of Inside Money", The Economics of Transition. Vol. 2 no.1 (1994), 71-81.

Perotti, Enrico (1995). 'Credible Privatization'. American Economic Review, Volume 85, Number 4, pp. 847-859.

Perotti, Enrico (2002). 'Lessons from the Russian Meltdown: The Economics of Soft Legal Constraints', International Finance Vol 5 no 3, pp.359-399.

Pistor, Katharina and Chenggang Xu"(2002), Incomplete Law", working paper, LSE, London.

Sappington, David. E.M., Joseph E. Stiglitz (1987). 'Privatization, Information, and Incentives'. NBER Working Paper \#2196.

Schmidt, Klaus (1996). "The Costs and Benefits of Privatization - An Incomplete Contracts Approach", Journal of Law, Economics and Organization, 12, pp. 1-24.

Sheshinski, Eytan, and Luis Felipe López-Calva (1998). Privatization And Its Benefits: Theory And Evidence, CAER Discussion Paper, Harvard Institute of International Development, Cambridge, MA.

Shirley, Mary M., and Patrick Walsh (2000). 'Public versus Private Ownership: The Current State of the Debate'. World Bank, Development Research Group, Washington, D.C., Policy Research Working Paper 2420.

Shleifer, Andrei, and Robert. W. Vishny (1993). 'Corruption'. The Quarterly Journal of Economics, Volume 108, Issue 3, pp. 599-617. 
Shleifer, Andrei, and Robert. W. Vishny (1994). 'Politicians and Firms'. The Quarterly Journal of Economics, Volume 109, Issue 4, pp. 995-1025.

Shleifer, Andrei (1998). 'State versus Private Ownership'. The Journal of Economic Perspectives, Volume 12, Issue 4, pp. 133-150.

Vickers and Yarrow (1989): 'Privatisation', MIT Press.

World Bank (1995). 'Bureaucrats in Business'. London, OUP. 